\title{
Occurence and antimicrobial resistance of Arcobacter species in food and slaughterhouse samples
}

\author{
Mehmet ELMALI ${ }^{1}$, Hayriye Yeşim CAN ${ }^{1 *}$
}

\begin{abstract}
The objectives of this study were: i) to isolate Arcobacter species (Arcobacter butzleri, Arcobacter skirrowii, Arcobacter cryaerophilus) from different foods and sources, ii) to verify the isolates by multiplex PCR assay, iii) to detect the antibiotic resistance profiles of the isolates. In this study a total of 60 Arcobacter isolates were obtained. Arcobacter species were mostly isolated from swab samples (40\%), followed by wastewater (29.1\%), broiler wing meat (30\%), raw milk (23.9\%) and minced meat (6.6\%). Regarding the seasonal distribution of Arcobacter from swab and wastewater samples, the bacterium was commonly isolated from wastewater in winter and spring, while it was frequently detected in swab samples during autumn and spring. All of the isolates were found to be resistant to nalidixic acid, ampicillin, rifampin, and erythromycin. The most effective antibiotic was tetracycline, because $96.66 \%$ of the isolates were susceptible against it. This is the first report of the isolation, seasonal distribution and antimicrobial susceptibility of Arcobacter species in cattle slaughterhouse samples in Turkey. These results indicate that foods of animal origin and cattle slaughterhouses are significant source of the antimicrobial resistant arcobacters.
\end{abstract}

Keywords: Arcobacter; antimicrobial resistance; raw milk; minced meat; wastewater.

Practical Application: To reveal the presence of Arcobacter species in foods and cattle slaughterhouse samples.

\section{Introduction}

Arcobacter are an important pathogenic bacteria known as zoonosis. They are aerotolerant, Gram-negative bacteria that can grow under both aerobic and microaerophilic conditions, and optimally grow at $30{ }^{\circ} \mathrm{C}$. They are motile and most strains are non-hemolytic. Arcobacter is one of the genera within the family Campylobacteraceae. Arcobacter butzleri, Arcobacter cryaerophilus, Arcobacter skirrowii, Arcobacter nitrofigilis, Arcobacter cibarius and Arcobacter halophilus are the most well known species in the genera (Fernandez et al., 2015; Giacometti et al., 2015a; Harmon \& Wesley, 1996; Van den Abeele et al., 2014).

Some researches have reported that $A$. butzleri, A. cryaerophilus and A. skirrowii have been associated with human and animal infections. These species are considered as emerging pathogens and have been isolated from patients with bacteraemia, endocarditis, peritonitis and diarrhea. They cause abortion, mastitis and diarrhea in farm animals. Colonised healthy animals are also an important source of Arcobacter species (Alonso et al., 2014; Collado et al., 2014; Corry \& Atabay, 2001; Girbau et al., 2015; Houf et al., 2000).

Arcobacters are transmitted by food and water. Especially since the 2000s studies conducted on this subject came into prominence in the world. After this term, Arcobacter species have been isolated from different foods and sources such as raw milk, cheese, chicken, pork and beef meats, water, sewage water, seafood and fecal samples in many countries including Turkey (Akıncioglu, 2011; Atabay et al., 2003; Aydin et al.,
2007; Çelik \& Ünver, 2015; Ertas et al., 2010; Yesilmen et al., 2014), Iran (Khoshbakht et al., 2014; Rahimi et al., 2012), Italy (Giacometti et al., 2015a, b), Costa Rica (Bogantes et al., 2015), Germany (Lehmann et al., 2015), India (Ramees et al., 2014; Verma et al., 2015), Czech Republic (Šilha et al., 2015), Poland (Zacharow et al., 2015), Spain (Alonso et al., 2014), Belgium (Van den Abeele et al., 2014).

Limited information about the presence and antimicrobial susceptibility profiles of Arcobacters in foods and cattle slaughterhouse sources is available in Turkey. Therefore, in this study, we aimed to determine the prevalence of Arcobacter species in some foods (raw milk, broiler meat, minced meat) and cattle slaughterhouse samples (wastewater, swab), and to investigate the antimicrobial resistance profiles of the isolates.

\section{Materials and methods}

\subsection{Sample collection}

In this study, a total of 229 various samples were analysed. Samples including 40 frozen broiler wing meat, 45 minced beef meat samples, and 46 raw cow milk were collected in Hatay Region, Turkey. Between June 2014-May 2015, 50 swabs taken from the tools and equipment (e.g. knives, meat chopping boards) in cattle slaughterhouses, and 48 slaughterhouse wastewater discharged after cutting process were also used as materials in the study. The slaughterhouse samples were collected during 
every month. The samples were immediately transported to the laboratory in a cool box for analysis.

\subsection{Isolation media}

For isolation Arcobacter spp., Arcobacter Enrichment Broth (AEB; Oxoid, Basingstoke, Hampshire, England), BBL ${ }^{\mathrm{Tm}}$ Blood Agar Base (BA; Le Pont de Claix, France), and Campylobacter Blood-Free Base Bolton (mCCDA; Biolife, Milano, Italia) were used. AEB was used with adding cefoperazon-amphotericin B-teicoplanin (CAT) selective supplement (Oxoid). BA was used with adding $5 \%$ defibrinated sheep blood. mCCDA was prepared with using CCDA selective supplement (Oxoid). All of isolation mediums were used together with gas generating kits (Oxoid) for making a microaerophilic condition for Arcobacter isolation (Atabay \& Corry, 1997).

\subsection{Membrane filtration technique}

For the isolation of Arcobacter, we used membrane filtration technique. After preenrichment, $300 \mu \mathrm{L}$ of each enriched samples were plated onto BA using cellulose acetate membrane filters (Filterlab, Barcelona, Spain) with a pore size of $0.45 \mu \mathrm{M}$ according to the Atabay et al. (2003). The filters were removed after $30 \mathrm{~min}$, and the inoculum passing through the filter was streaked on the agar by using loop. Then, the plates were incubated microaerobically at $30^{\circ} \mathrm{C}$ for $48-72 \mathrm{~h}$. Suspect colonies were sub-cultured on mCCDA and incubated microaerobically at $30{ }^{\circ} \mathrm{C}$ for $48-72 \mathrm{~h}$. Opaque and whitish-gray colonies were selected for DNA extraction.

\section{Isolation of Arcobacter from minced beef meat}

In this study, we modified isolation prodecure reported by Aydin et al. (2007) as below. Ten grams of minced beef meat samples were added to $90 \mathrm{~mL}$ of AEB, and homogenised with stomacher (Bagmixer400, Interscience, France) for $2 \mathrm{~min}$. Then, the homogenates were incubated in microaerophilic conditions at $30{ }^{\circ} \mathrm{C}$ for $48 \mathrm{~h}$ for preenrichment.

\section{Isolation of Arcobacter from broiler wing meat}

In the present study, we made some changes to isolation method for broiler meat reported by Aydin et al. (2007). Twenty five grams of broiler wing meat samples were suspended with $225 \mathrm{~mL} \mathrm{AEB}$, and homogenised for $2 \mathrm{~min}$. Then, they were incubated microaerobically at $30^{\circ} \mathrm{C}$ for $48 \mathrm{~h}$ for preenrichment.

\section{Isolation of Arcobacter from raw milk}

Preenrichment procedure of Atabay et al. (2003) for milk samples was performed with some modifications. AEB was added onto $20 \mathrm{~mL}$ of each raw milk sample, mixed throughly, and incubated microaerobically at $30^{\circ} \mathrm{C}$ for $48 \mathrm{~h}$ for preenrichment.

\section{Isolation of Arcobacter from swabs}

We modified preenrichment procedure for swab samples described by Aydin et al. (2007). Twenty mililiters of AEB was added to swab samples, mixed throughly, and incubated microaerobically at $30^{\circ} \mathrm{C}$ for $48 \mathrm{~h}$ for preenrichment.

\section{Isolation of Arcobacter from wastewater samples}

Slaughterhouse wastewater samples $(20 \mathrm{~mL})$ were added to $20 \mathrm{~mL}$ of AEB, mixed throughly, and incubated microaerobically at $30{ }^{\circ} \mathrm{C}$ for $48 \mathrm{~h}$ for preenrichment. The isolation procedure was carried out according to the Aydin et al. (2007).

\subsection{Verification of Arcobacter spp. by PCR analysis}

DNA extraction was performed using a Bacterial DNA Extraction kit (Nucleic Acid Extraction Kit, GF-1, Vivantis, Malaysia), following the kit manufacturer's instructions and extracted DNA samples were stored at $-20{ }^{\circ} \mathrm{C}$ until the PCR analysis.

For Arcobacter spp., primers described by Harmon \& Wesley (1996) were used. PCR mixture of Akıncıoğlu (2011) was performed in a total volume of $30 \mu \mathrm{L}$ containing $2 \mu \mathrm{L}$ of template DNA, $2.5 \mu \mathrm{L}$ of Taq 10xbuffer (Thermoscientific, Lithuania), $1.5 \mathrm{mM} \mathrm{MgCI}_{2}$ (Thermoscientific), $0.2 \mathrm{mM}$ deoxynucleoside triphosphate mixture (EURx, Poland), $0.16 \mu \mathrm{M}$ of primers (Ella Biotech, Germany), and 1.5 U Taq DNA polymerase (Thermoscientific). PCR amplification conditions were carried out as below: initial denaturation at $94^{\circ} \mathrm{C}$ for $4 \mathrm{~min}$, followed by 29 cycles of denaturation at $94^{\circ} \mathrm{C}$ for $1 \mathrm{~min}$, annealing at $56^{\circ} \mathrm{C}$ for $1 \mathrm{~min}$, extension at $72{ }^{\circ} \mathrm{C}$ for $1 \mathrm{~min}$, with a final extension at $72{ }^{\circ} \mathrm{C}$ for $7 \mathrm{~min}$ (Akıncıoğlu, 2011; Harmon \& Wesley, 1996).

\subsection{Identification of Arcobacter spp. by multiplex PCR analysis}

To detect A. butzleri, A. skirrowii, and A. cryaerophilus, specific primer pairs described by Houf et al. (2000) were used. For the verification of A. butzleri, A. skirowii, and A. cryaerophilus, PCR master mix was prepared with the same concentrations as indicated above. Akıncıoğlu (2011)'s DNA amplification protocol was carried out with an initial denaturation of $94^{\circ} \mathrm{C}$ for $3 \mathrm{~min}$, followed by 34 cycles of denaturation at $94{ }^{\circ} \mathrm{C}$ for $30 \mathrm{~s}$, annealing at $60{ }^{\circ} \mathrm{C}$ for $30 \mathrm{~s}$, and extension at $72{ }^{\circ} \mathrm{C}$ for $1 \mathrm{~min}$. Final extension cycle was performed at $72{ }^{\circ} \mathrm{C}$ for $7 \mathrm{~min}$. Amplified PCR products were detected by electrophoresis in $\% 1.5$ agarose (Sigma-Aldrich, St Louis, USA) at $100 \mathrm{~V}$ for $1 \mathrm{~h}$ (CS-300V, Cleaver Scientific, England). The bands were then visualised under a UV transilluminator (UVP, Upland, USA).

\subsection{Antimicrobial susceptibility}

Antimicrobial susceptibility testing of the Arcobacter isolates against 9 antibiotics was performed on Mueller-Hinton agar (Oxoid) by the disk diffusion method according to the guidelines of the Clinical and Laboratory Standards Institute (CLSI) (CLSI, 2015). Tested antibiotics were as follows: erythromycin $(15 \mu \mathrm{g} / \mathrm{disc})$, nalidixic acid (5 $\mu \mathrm{g} /$ disc $)$, ampicillin $(10 \mu \mathrm{g} / \mathrm{disc})$, tetracycline $(30 \mu \mathrm{g} / \mathrm{disc})$, iminepem $(10 \mu \mathrm{g} / \mathrm{disc})$, gentamicin $(10 \mu \mathrm{g} / \mathrm{disc})$, ciprofloxacin $(5 \mu \mathrm{g} / \mathrm{disc})$, rifampin $(5 \mu \mathrm{g} / \mathrm{disc})$, azithromycin (15 $\mu \mathrm{g} / \mathrm{disc})$. The Arcobacter isolates were sub-cultured on BA and incubated at $30^{\circ} \mathrm{C}$ for $48 \mathrm{~h}$. Colonies were then suspended in saline solution $(0.5 \%)$ for adjusting the turbidity of the suspension to MacFarland 0.5 standard. Each suspension was inoculated on Mueller-Hinton agar with a sterile cotton swab. The plates were 
incubated aerobically at $30^{\circ} \mathrm{C}$ for $48-72 \mathrm{~h}$. Then, the diameters of inhibition zones were measured and the isolates were classified as susceptible, intermediate resistant, and resistant.

\section{Results}

\subsection{Contamination with Arcobacter species}

In this study, sixty (26.2\%) of the samples were found to be contaminated with Arcobacter. Arcobacter spp. were isolated from $23.9 \%, 30 \%, 6.6 \%, 29.1 \%$ and $40 \%$ of raw milk, broiler wing meat, minced meat, wastewater, and swab samples, respectively.

A total of 60 Arcobacter isolates were obtained in this study, and isolates were identified at species level using multiplex PCR (Figure 1). Among these isolates, 23 were identified as A. butzleri, one was A. skirrowii, and six were A. cryaerophilus. Of these isolates, 11 were also detected as A. butzleri + A. skirrowii + A. cryaerophilus, 7 were A. butzleri + A. cryaerophilus, 3 were A. cryoaerophilus + A. skirrowii and 4 were A. butzleri + A. skirrowii. Five of these isolates were determined as other Arcobacter species (Table 1). Also, in this study, the most prevalent species was A. butzleri at a level of $38.3 \%(23 / 60)$, followed by $10 \%(6 / 60)$ A. cryaerophilus and $1.6 \%(1 / 60)$ A. skirrowii. A. butzleri was more frequently recovered from wastewater samples $(78.5 \%)$, followed by broiler meat (41.6\%), minced meat (33.3\%), and swab samples (30\%). A. skirrowii was only determined in minced

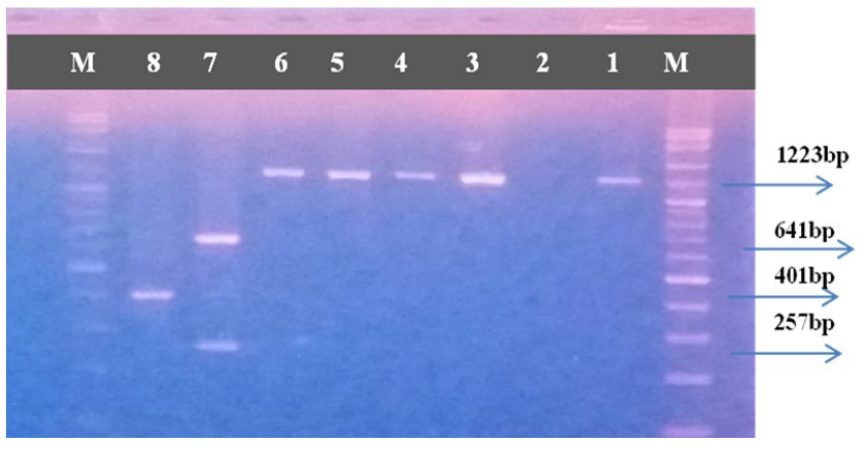

Figure 1. Agarose gel electrophoresis of Arcobacter spp.; A. butzleri; A.skirrowii and A. cryaerophilus. Lane M, 100 bp plus DNA ladder (Bioron, Germany); Lane 1, positive control; Lane 2, negative control; Lane 3-6, Arcobacter spp.; Lane 7: A. skirrowii + A. cryaerophilus; Lane 8: A. butzleri. meat. A. cryaerophilus was more commonly isolated from raw milk (36.3\%) and broiler meat (16.6\%) in the present study.

\subsection{Seasonal and monthly distribution of the isolates from swab and wastewater samples}

In the present study, a total of 98 cattle slaughterhouse samples including 50 swabs and 48 wastewater were collected during every month. Then, the samples were tested for the presence of Arcobacter species and the results were evaluated according to the months and seasons. Overall, according to the monthly and seasonal distributions of the isolates from wastewater samples, the contamination level was found to be $10.4 \%(5 / 48)$ in winter and spring, while it was $4.1 \%(2 / 48)$ in summer and autumn. In addition, all of the wastewater samples collected during December were found to be contaminated with Arcobacter spp (Table 2).

In the evaluation of the isolates recovered from swab samples according to the months and seasons, Arcobacter was not detected in any of the samples collected during winter. Arcobacter spp. was recovered from the swab samples with a rate of $8 \%(4 / 50)$, $14 \%(7 / 50)$, and $18 \%(9 / 50)$ in summer, spring, and autumn, respectively (Table 2 ). Also, a total of six swab samples were taken only in November and Arcobacter was detected in all of them.

\subsection{Antimicrobial susceptibility}

Now, there are no zone diameter interpretive criteria for comparison of the antibiotic resistance level of Arcobacter spp., so that the antibiotic susceptibility results of the isolates for nalidixic acid, ampicillin, tetracycline, imipenem, gentamicin, ciprofloxacin and azithromycin were compared with Enterobactericeae standards, while resistance to rifampin and erythromycin were evaluated according to Staphylococcus spp. standards of CLSI (2015). The results are shown in Table 3.

As a result of antibiotic susceptibility test, all of the Arcobacter isolates were found to be resistant to nalidixic acid, ampicillin, rifampin, and erythromycin. Resistance to ciprofloxacin gentamicin, and azithromycin was found to be $16.66 \%, 21.66 \%$, and $23.33 \%$ among the isolates, respectively. The most effective antibiotic was tetracycline, because $96.66 \%$ of the isolates were susceptible against it. Resistance to imipenem was found very high (96.66\%) among the isolates. In this study, all of the isolates were found to be resistant to one or more antibiotics tested.

Table 1. Distribution of Arcobacter species in analysed samples.

\begin{tabular}{|c|c|c|c|c|c|c|c|c|c|c|}
\hline Samples & $\begin{array}{c}\mathrm{N} \text { of } \\
\text { samples }\end{array}$ & Arcobacter spp. & A.b & A.s & A. $c$ & $\begin{array}{c}A . b+A . s+ \\
A . c\end{array}$ & $\begin{array}{l}\text { A. } b+ \\
\text { A. } c\end{array}$ & $\begin{array}{c}\text { A. } c+ \\
\text { A. } s\end{array}$ & $A . b+A . s$ & $\begin{array}{c}\text { Other } \\
\text { Arcobacter spp. }\end{array}$ \\
\hline Raw milk & 46 & $11(23.9 \%)$ & 0 & 0 & $4(36.3 \%)$ & $5(45.4 \%)$ & 0 & $1(9.0 \%)$ & 0 & $1(9.0 \%)$ \\
\hline $\begin{array}{l}\text { Broiler } \\
\text { meat }\end{array}$ & 40 & $12(30 \%)$ & $5(41.6 \%)$ & 0 & $2(16.6 \%)$ & 0 & $3(25 \%)$ & 0 & 0 & $2(16.6 \%)$ \\
\hline $\begin{array}{l}\text { Minced } \\
\text { meat }\end{array}$ & 45 & $3(6.6 \%)$ & $1(33.3 \%)$ & $1(33.3 \%)$ & 0 & 0 & 0 & 0 & $1(33.3 \%)$ & 0 \\
\hline $\begin{array}{l}\text { Waste } \\
\text { water }\end{array}$ & 48 & $14(29.1 \%)$ & $11(78.5 \%)$ & 0 & 0 & $2(14.2 \%)$ & 0 & 0 & 0 & $1(7.1 \%)$ \\
\hline Swab & 50 & $20(40 \%)$ & $6(30 \%)$ & 0 & 0 & $4(20 \%)$ & $4(20 \%)$ & $2(10 \%)$ & $3(15 \%)$ & $1(5 \%)$ \\
\hline Total & 229 & $60(26.2 \%)$ & $23(38.3 \%)$ & $1(1.6 \%)$ & $6(10 \%)$ & $11(18.3 \%)$ & $7(11.6 \%)$ & $3(5 \%)$ & $4(6.6 \%)$ & $5(8.3 \%)$ \\
\hline
\end{tabular}

A.b: A. butzleri; A.s: A. skirrowii; A.c: A. cryaerophilus. 
Table 2. The monthly/seasonal distribution of Arcobacter isolated from swab and wastewater samples.

\begin{tabular}{|c|c|c|c|c|c|c|c|c|c|c|c|c|}
\hline \multirow{3}{*}{ Samples } & \multicolumn{12}{|c|}{ Sampling period } \\
\hline & \multicolumn{3}{|c|}{ Summer (2014) } & \multicolumn{3}{|c|}{ Autumn (2014) } & \multicolumn{3}{|c|}{ Winter (2014-2015) } & \multicolumn{3}{|c|}{ Spring (2015) } \\
\hline & June & July & Aug. & Sept. & Oct. & Nov. & Dec. & Jan. & Feb. & Mar. & Apr. & May \\
\hline $\begin{array}{l}\text { Wastewater } \\
(n=14)\end{array}$ & 2 & 0 & 0 & 0 & 2 & 0 & 4 & 0 & 1 & 0 & 3 & 2 \\
\hline $\begin{array}{l}\text { Swab } \\
(n=20)\end{array}$ & 3 & 0 & 1 & 1 & 2 & 6 & 0 & 0 & 0 & 2 & 2 & 3 \\
\hline
\end{tabular}

Table 3. Antimicrobial resistance profile of Arcobacter isolates $(n=60)$.

\begin{tabular}{lccc}
\hline Antimicrobials & Resistant $n(\%)$ & $\begin{array}{c}\text { Intermediate } \\
n(\%)\end{array}$ & $\begin{array}{c}\text { Susceptible } n \\
(\%)\end{array}$ \\
\hline Nalidixic acid & $60(100)$ & 0 & 0 \\
Ampicillin & $60(100)$ & 0 & 0 \\
Tetracycline & $2(3.33)$ & 0 & $58(96.66)$ \\
Imipenem & $58(96.66)$ & $1(1.66)$ & $1(1.66)$ \\
Gentamicin & $5(8.33)$ & $8(13.33)$ & $47(78.33)$ \\
Ciprofloxacin & $4(6.66)$ & $6(10)$ & $50(83.33)$ \\
Azithromycin & $14(23.33)$ & 0 & $46(76.66)$ \\
Rifampin & $60(100)$ & 0 & 0 \\
Erythromycin & $60(100)$ & 0 & 0 \\
\hline
\end{tabular}

\section{Discussion}

When we examine studies conducted in Turkey regarding the determination of contamination levels of animal food products with Arcobacter, we can see that Atabay et al. (2003) found 65.3\% contamination on chicken carcasses, while Aydin et al. (2007) found $68 \%, 4 \%$ and $37 \%$ contamination in chicken meat, turkey meat, and minced meat, respectively. Consistent with these studies, Arcobacter was isolated most frequently from broiler meat among the food samples analysed in our study. Again supporting these findings, Corry \& Atabay (2001) have reported very high levels of Arcobacter spp. contamination in poultry meat. Similar to studies carried out by Aydin et al. (2007), Ertas et al. (2010) and Yesilmen et al. (2014) most identified species in the samples was $A$. butzleri. In some samples, they also found Arcobacter species as parts of a mixed culture. In our study, the level of Arcobacter spp. contamination in raw milk was found to be $23.9 \%$. Our finding was lower than the contamination level (36\%) in the study of Yesilmen et al. (2014), but it was high as compared with the study (6\%) of Ertas et al. (2010).

In other studies, Çelik \& Ünver (2015), Akıncıoğlu (2011) detected Arcobacter spp. with a rate of $12.3 \%$ and $37 \%$, respectively in various water sources. While Aydin et al. (2007), Çelik \& Ünver (2015) found no Arcobacter in drinking water samples, Ertas et al. (2010) and Akıncıoğlu (2011) found the bacteria in drinking water. In this study, we found high levels of Arcobacter spp. contamination in slaughterhouse wastewater samples (29.1\%) and in swab samples taken from meat cutting boards and knives (40\%). A. butzleri was the predominant species isolated from the cattle slaughterhouse samples. In addition, we've observed that the slaughterhouse samples taken in spring and autumn have more contamination of the bacteria. To our knowledge, this study is the first report in this regard in Turkey. Considering these results, we think that meat cutting boards and knives may constitute a potential risk for the contamination of red meat with Arcobacter.

When we examine researches conducted in other countries in this regard, we can see that Zacharow et al. (2015) and Khoshbakht et al. (2014) found contamination of meat samples with Arcobacter to be much higher than our study (40.4\% and $45 \%$ respectively, whereas our study had $17.6 \%$ contamination). While Bogantes et al. (2015) observed a low prevalence of Arcobacter in poultry (11\%), Kabeya et al. (2004) and Rahimi et al. (2012) determined a high prevalence of Arcobacter in poultry, which is similar to our study. In accordance to above studies, the predominant species was $A$. butzleri in the meat samples. While Verma et al. (2015) found the level of Arcobacter contamination in various animal products and environmental samples as $11.3 \%$ lower than our study, Šilha et al. (2015) found a contamination level of $36.8 \%$, higher than our findings. Similarly, Verma et al. (2015) detected A. butzleri, A. skirrowii, and A. cryaerophilus as parts of a mixed culture in some samples. Giacometti et al. (2015b) determined Arcobacter at a level of $22.6 \%$ in samples taken from a dairy farm and similarly found that $A$. cryaerophilus was the predominant species in the milk. Lehmann et al. (2015) found Arcobacter contamination of fish meat, poultry and minced meat as $34 \%, 26.8 \%$ and $2 \%$, respectively. In Chile, studies of Collado et al. (2014) and Fernandez et al. (2015) have shown that $A$. butzleri was the most frequently isolated species also in sea products.

As a result, it can be seen that foods of animal origin, sea products and water sources are contaminated with Arcobacter and contamination levels are varied. This variation may be a result of the fact that studies were conducted in different regions, and that isolation methods used have different sensitivity levels.

There is limited information about the antimicrobial susceptibility of Arcobacter. In line with our findings, Collado et al. (2014), Akıncioğlu (2011) found high resistance to nalidixic acid and ampicillin among the Arcobacter strains. Akıncıoğlu (2011), Yesilmen et al. (2014), Zacharow et al. (2015) and we found high resistance to erythromycin, different from Collado et al. (2014) and Kabeya et al. (2004). Only four isolates were resistant and six isolates were intermediately resistant to ciprofloxacin in the present study.

Yesilmen et al. (2014) reported that the acquired resistance to tetracycline and ampicillin among the foodborne isolates 
may raise concern for the treatment of Arcobacter infections in humans and animals, since both of these antibiotics are generally prefered. In this study, susceptibility to tetracycline was very high among the isolates. Zacharow et al. (2015), Akıncioğlu (2011), Kabeya et al. (2004), Atabay \& Aydin (2001) found Arcobacter strains susceptible to tetracycline in contrast to Yesilmen et al. (2014).

In conclusion, our results show that the presence of Arcobacter species in foods of animal origin and cattle slaughterhouse samples. Because of this, raw milk, minced meat, broiler meat and also knives, meat chopping boards and wastewater in cattle slughterhouse are considered to be an important source of Arcobacter species. At the same time, all of Arcobacter isolates recovered from these samples were found to be resistant to one or more antibiotics tested. Therefore, these results should be taken into account when controlling the contamination with Arcobacter and also treating the infections caused by Arcobacter species in animals and humans.

\section{Acknowledgements}

The present study was financially supported by the project 12122 from the Mustafa Kemal University.

\section{References}

Akıncioğlu, F. (2011). Isolation of Arcobacter species from different water sources and characterization of isolated species by molecular techniques (Master thesis). İzmir Institute of Technology, İzmir.

Alonso, R., Girbau, C., Martinez-Malaxetxebarria, I., \& FernándezAstorga, A. (2014). Multilocus sequence typing reveals genetic diversity of foodborne Arcobacter butzleri isolates in the North of Spain. International Journal of Food Microbiology, 191, 125-128. PMid:25261830. http://dx.doi.org/10.1016/j.ijfoodmicro.2014.09.012.

Atabay, H. I., \& Aydin, F. (2001). Susceptibility of Arcobacter butzleri isolates to 23 antimicrobial agents. Letters in Applied Microbiology, 33(6), 430-433. PMid:11737626. http://dx.doi.org/10.1046/j.1472765X.2001.01025.x.

Atabay, H. I., \& Corry, J. E. L. (1997). The prevalence of campylobacters and arcobacters in broiler chickens. Journal of Applied Microbiology, 83(5), 619-626. PMid:9418023. http://dx.doi.org/10.1046/j.13652672.1997.00277.x.

Atabay, H. I., Aydin, F., Houf, K., Sahin, M., \& Vandamme, P. (2003). The prevalence of Arcobacter spp. on chicken carcasses sold in retail markets in Turkey, and identification of the isolates using SDS-PAGE. International Journal of Food Microbiology, 81(1), 21-28. PMid:12423915. http://dx.doi.org/10.1016/S0168-1605(02)00163-0.

Aydin, F., Gümüşsoy, K. S., Atabay, H. I., Iça, T., \& Abay, S. (2007). Prevalence and distribution of Arcobacter species in various sources in Turkey and molecular analysis of isolated strains by ERIC-PCR. Journal of Applied Microbiology, 103(1), 27-35. PMid:17584450. http://dx.doi.org/10.1111/j.1365-2672.2006.03240.x.

Bogantes, E. V., Fallas-Padilla, K. L., Rodriguez-Rodriguez, C. E., Jaramillo, H. F., \& Echandi, M. L. A. (2015). Zoonotic species of the genus Arcobacter in poultry from different regions of Costa Rica. Journal of Food Protection, 78(4), 808-811. PMid:25836409. http:// dx.doi.org/10.4315/0362-028X.JFP-14-494.

Çelik, E., \& Ünver, A. (2015). Isolation and identification of Arcobacter spp. by multiplex PCR from water sources in Kars region. Current
Microbiology, 71(5), 546-550. PMid:26210902. http://dx.doi. org/10.1007/s00284-015-0883-x.

Clinical and Laboratory Standards Institute - CLSI. (2015). Performance standards for antimicrobial susceptibility testing (25th informational supplement - M100- S25). Wayne: CLSI.

Collado, L., Jara, R., Vasquez, N., \& Telsaint, C. (2014). Antimicrobial resistance and virulence genes of Arcobacter isolates recovered from edible bivalve molluscs. Food Control, 46, 508-512. http://dx.doi. org/10.1016/j.foodcont.2014.06.013.

Corry, J. E. L., \& Atabay, H. I. (2001). Poultry as a source of Campylobacter and related organisms. Journal of Applied Microbiology, 90(30), 96S-114S. PMid:11422565. http://dx.doi.org/10.1046/j.13652672.2001.01358.x.

Ertas, N., Dogruer, Y., Gonulalan, Z., Guner, A., \& Ulger, I. (2010). Prevalence of Arcobacter species in drinking water, spring water and raw milk as determined by multiplex PCR. Journal of Food Protection, 73(11), 2099-2102. PMid:21219725.

Fernandez, H., Villanueva, M. P., Mansilla, I., Gonzalez, M., \& Latif, F. (2015). Arcobacter butzleri and A. cryaerophilus in human, animals and food sources, in Southern Chile. Brazilian Journal of Microbiology, 46(1), 145-147. PMid:26221100. http://dx.doi.org/10.1590/S1517838246120140095 .

Giacometti, F., Lucchi, A., Di Francesco, A., Delogu, M., Grilli, E., Guarniero, I., Stancampiano, L., Manfreda, G., Merialdi, G., \& Serraino, A. (2015a). Arcobacter butzleri, Arcobacter cryaerophilus, and Arcobacter skirrowii circulation in a dairy farm and sources of milk contamination. Applied and Environmental Microbiology, 81(15), 5055-5063. PMid:26002896. http://dx.doi.org/10.1128/ AEM.01035-15.

Giacometti, F., Salas-Masso, N., Serraino, A., \& Figueras, M. J. (2015b). Characterization of Arcobacter suis isolated from water buffalo (Bubalus bubalis) milk. Food Microbiology, 51, 186-191. PMid:26187844. http://dx.doi.org/10.1016/j.fm.2015.06.004.

Girbau, C., Guerra, C., Martinez-Malaxetxebarria, I., Alonso, R., \& Fernandez-Astorga, A. (2015). Prevalence of ten putative virulence genes in the emerging foodborne pathogen Arcobacter isolated from food products. Food Microbiology, 52, 146-149. PMid:26338128. http://dx.doi.org/10.1016/j.fm.2015.07.015.

Harmon, K. M., \& Wesley, I. V. (1996). Identification of Arcobacter isolates by PCR. Letters in Applied Microbiology, 23(4), 241-244. PMid:8987697. http://dx.doi.org/10.1111/j.1472-765X.1996.tb00074.x.

Houf, K., Tutenel, A., De Zutter, L., Van Hoof, J., \& Vandamme, P. (2000). Development of a multiplex PCR assay for the simultaneous detection and identification of Arcobacter butzleri, Arcobacter cryaerophilus and Arcobacter skirrowii. FEMS Microbiology Letters, 193(1), 89-94. PMid:11094284. http://dx.doi.org/10.1111/j.1574-6968.2000.tb09407.x.

Kabeya, H., Maruyama, S., Morita, Y., Ohsuga, T., Ozawa, S., Kobayashi, Y., Abe, M., Katsube, Y., \& Mikami, T. (2004). Prevalence of Arcobacter species in retail meats and antimicrobial susceptibility of the isolates in Japan. International Journal of Food Microbiology, 90(3), 303-308. PMid:14751685. http://dx.doi.org/10.1016/S0168-1605(03)00322-2.

Khoshbakht, R., Tabatabaei, M., Aski, H. S., \& Seifi, S. (2014). Occurence of Arcobacter in Iranian poultry and slaughterhouse samples implicates contamination by processing equipment and procedures. British Poultry Science, 55(6), 732-736. PMid:25274202. http://dx.doi.org /10.1080/00071668.2014.971223.

Lehmann, D., Alter, T., Lehmann, L., Uherkova, S., Seidler, T., \& Golz, G. (2015). Prevalence, virulence gene distribution and genetic diversity of Arcobacter in food samples in Germany. Berliner und Munchener Tierarztliche Wochenschrift, 128, 163-168. Retrieved from http://vetline.de/open-access/158/3216. 
Rahimi, E., Hormozipoor, H., Ahangaran, M.G., \& Yazdi, F. (2012). Prevalence of Arcobacter species on chicken carcasses during processing in Iran. The Journal of Applied Poultry Research, 21(2), 407-412. http://dx.doi.org/10.3382/japr.2011-00494.

Ramees, T. P., Rathore, R. S., Bagalkot, P. S., Sailo, B., Mohan, H. V., Kumar, A., Dhama, K., \& Singh, R. K. (2014). Genotyping and genetic diversity of Arcobacter butzleri and Arcobacter cryaerophilus isolated from different sources by using ERIC- PCR from India. The Veterinary Quarterly, 34(4), 211-217. PMid:25333916. http://dx.doi. org/10.1080/01652176.2014.979511.

Šilha, D., Šilhová-Hrušková, L., \& Vytřasová, J. (2015). Modified isolation method of Arcobacter spp. from different environmental and food samples. Folia Microbiologica, 60(6), 515-521. PMid:25912846. http://dx.doi.org/10.1007/s12223-015-0395-x.

Van den Abeele, A. M., Vogelaers, D., Van Hende, J., \& Houf, K. (2014). Prevalence of Arcobacter species among humans, Belgium, 2008-2013.
Emerging Infectious Diseases, 20(10), 1731-1734. PMid:25271569. http://dx.doi.org/10.3201/eid2010.140433.

Verma, M., Joshi, N., Rathore, R. S., \& Mohan, H. V. (2015). Detection of Arcobacter spp. in poultry, pigs, their meat and environmental samples by conventional and PCR assays. The Indian Journal of Animal Sciences, 85(9), 954-957.

Yesilmen, S., Vural, A., Erkan, M. E., \& Yildirim, I. H. (2014). Prevalence and antimicrobial susceptibility of Arcobacter species in cow milk, water buffalo milk and fresh village cheese. International Journal of Food Microbiology, 188, 11-14. PMid:25064812. http://dx.doi. org/10.1016/j.ijfoodmicro.2014.07.006.

Zacharow, I., Bystron, J., Walecka-Zacharska, E., Podkowik, M., \& Bania, J. (2015). Prevalence and antimicrobial resistance of Arcobacter butzleri and Arcobacter cryaerophilus isolates from retail meat in Lower Silesia region, Poland. Polish Journal of Veterinary Sciences, 18(1), 63-69. PMid:25928911. http://dx.doi.org/10.1515/pjvs-2015-0008. 